\title{
Effects of Forest Disturbance on Plant Species Composition and Forest Structure: A Case Study of Kapkanyar Power Line in Cherangani Forest
}

\author{
Josephat Makokha', Emmy Kerich ${ }^{2}$, Daniel Mkung ${ }^{3}$ \\ ${ }^{1,3}$ Ministry of Environment and Natural Resources, Elgeyo Marakwet County, Kenya, P.O BOX 21 Kapcherop, Kenya \\ ${ }^{2}$ Department of Biology and Health, School of Environmental Studies, University of Eldoret, P.O. BOX 1125, Eldoret, Kenya
}

\begin{abstract}
To ecologists and forest managers, an up to date data on forest botanical details is a pre-requisite to making management decisions from an informed perspective. Cherangani forest which is host to Kapkanyar power line project could be at risk of losing taxa of conservation significance in this and similar projects if right scientifically tested and proven data is not used to guide decisions. Considering that a number of infrastructures here and other state forests seldom commence prior to elaborate vegetation surveys, ecological disasters are bound to occur due to the ecosystem destabilization arising there from. This research spanned over a period of three months from April to July in 2015 with the objective of looking at the past records of woody plants (inventory data) and the present composition of taxa in all life forms of vascular plants to ascertain the effects of disturbance on the forest. Stratified systematic sampling was used to locate sample plots. Parameters like composition, disturbance regimes, cover, were analyzed in respect of identified flora in order to understand the forest community. The nomenclature and taxa description used was according to Bentjee (1994) and Agnew (2013).Standard methods of plant identification were used. Descriptive statistics was used in the analysis and data was presented in tables, graphs and charts. In this study we found 71 species distributed in 35 taxa. The results further gave the impression that disturbance reduced woody species presence while it increased the population of non perennial taxa. Fern and semi scandents were insignificantly affected by the disturbance. The structure of disturbed forest was reduced to undergrowth in most areas with undisturbed forest retaining multistorey canopies. This study recommends that government implements projects that have ecological dimensions with due diligence particularly in regard to conducting preliminary studies prior to commencement of the same.
\end{abstract}

Keywords: Forest disturbance, Plant species composition, Cherangani forest, Power line project

\section{Introduction}

Forests provide multiple ecosystem services that are critical to sustain societies and ecosystems (Gamfeldt et al., 2013). Protecting the forest systems becomes imperative as human demand for forest products and services increase (UNEP, 2012; Timothy and Ayten, 2013; IPCC, 2007). Disturbance is a major driving force that determines the transition of forest stands, landscapes, and regions (Raffa et al., 2008). Human influences on the disturbance regime include both direct effects, such as harvesting or inducing and or suppressing natural disturbances have indirect influences from altering the forest environment. Indirect influences include both climate change and atmospheric pollution, and their effects on tree health and survival (Raffa et al., 2008) and also play an important natural part in the lifecycle and succession dynamics of many forest systems (Meurant, 2012).

With the advent of ecosystem management and as a result of changing attitudes about disturbance processes, land managers have began to think about plant succession, competition, and other aspects of forest ecology in a different way (David, 2000). According to Nature Kenya, (2015), encroachment, poaching of trees, grazing and charcoal burning are the leading serious conservation problems associated with Cherangani ecosystem. While undertaking a rapid biodiversity survey of Cherangani ,Musila et al., (2011) concluded that previous studies were not tailored to address the ecological implications of human activities that could lead to forest disturbance, but mainly focused on botanical surveys that were rapid in implementation (PFMP, 2014) and that is why a foundational dataset characterizing historic forest disturbance dynamics and related resource impacts would be a powerful tool for identifying threshold disturbance patterns that negatively affect multiple forest resources (Pflugmacher et al., 2012).

In order obtain the requisite data set, botanical assessments such as floristic composition, species and structural analysis studies are essential for providing information on species richness of the forests (Guisan \& Thuiller, 2005).This is useful for forest management purpose and help in understanding forest ecology and ecosystem functions (Giriraj et al., 2008). Knowledge of floristic composition and structure of forest is also useful in identifying ecologically and economically important plants and their diversities, protecting threatened and economical important plant species (Tesfaye et al., 2013) and this is why Musila et al., (2011) recommended detailed studies after concluding that Cherangani was most diverse in floral species compared to Nandi ecosystem.

Two years after the disturbance (Tree cutting to pave way for power line), this study looks at the species composition, structure and diversity of the disturbed and adjacent undisturbed areas of the forest for the woody plants that was removed during the power line/road construction exercise and relate to the undergrowth in undisturbed areas to understand the herbaceous vegetation that was lost. This research aims at giving insights on the resilience of the forest

Volume 6 Issue 7, July 2017 www.ijsr.net 


\section{International Journal of Science and Research (IJSR) \\ ISSN (Online): 2319-7064}

Index Copernicus Value (2015): 78.96 | Impact Factor (2015): 6.391

especial in terms of community defining species and what disturbance predisposes the forest to. Extrapolation of the findings of this project will be used to derive criteria for predicting the impacts of projects of similar magnitude in same or corresponding ecological set ups. This dataset will allow us to evaluate how disturbance configuration over the years have influenced the current status of forest composition, structure and ultimately help to identify management responses that improve and sustain forest resources into the future. And therefore assist by putting in place modalities necessary to forestall anticipated ecological disasters for instance be alert on invasive species.

\section{Methodology}

\subsection{Study Area}

Kapkanyar power line is along five kilometers' stretch of road located in Cherangani forest in Rift Valley province and occurring within a bounding box defined by $1^{\circ} 16^{\prime}$ North $35^{\circ}$ 26 ' East. According to Birdlife International, (2009), the ecosystem is comprised of a series of forest reserves, about 13 administrative blocks, totaling 95,600 ha in gazetted area. Of this 60,500 ha is closed-canopy forest, the remainder being formations of bamboo, scrub, rock, grassland, moorland or heath, with 4000 ha of cultivation and plantations. Kapkanyar, Kapolet and Kipteber Forest Reserves together form a large western block of forest, totaling 20,000 ha. To the east, the Forest Reserves of Lelan, Embobut, Kerrer, Koisungur, Toropket, Chemurgoi, Kipkunur, Cheboyit, Sogotio and Kapchemutwa are less well connected. Apart from a large south-eastern bloc along the escarpment crest, the forests here are fragmented and separated by extensive natural grasslands, scrub and (especially in the central part) farmland. Kapkanyar is under Cherangani Forest Station (PFMP, 2014).

\subsection{Research Design}

The study area was divided into two study sites on the basis of disturbance i.e., disturbed (D) and undisturbed (UD) areas. The field work was carried out within three months from April and June 2015. This was to take advantage of the peak growing season for most species. Sampling was through stratified systematic protocols based on disturbance regimes. Five plots of twenty by one hundred meters were laid in each of the two strata at intervals of one kilometer measured by counting transmission poles used.

\subsection{Field Data Collection}

Collected data included plant nomenclature, Herbarium specimens, plant photographs, forest physiognomy, GPS (Global positioning system) coordinates, and plant diagnostic attributes that are volatile on specimens or those that could not be reflected on specimen due to their immobility or carpological nature. The plant names used were according to Bentjee, (1994) and Agnew, (2013). Specimen collection was done with due regard to principles of preservation and conservation according to Leonard and Bridson, (1999).

\subsection{Species identification and habit classification}

The writer did all specimen identification with aid of relevant keys either in the field or in office after specimen curation. Cured specimens was preserved for future reference with due regard to standard herbarium protocols (Bridson \& Leonard, 1999). The physiognomy was described according to Beentje, (1994).

\subsection{Data Analysis}

Data was cleaned and analyzed using statistical package of social scientist (SPSS version 16). Descriptive statistics was used to present plant distribution in disturbed areas and undisturbed areas. T- test was used to determine if there is a significant difference in plant distribution in disturbed areas and undisturbed areas

\section{Results}

\subsection{Species diversity}

Table 1: Types of plants species found in Kapkanyar Power line in Cherangani Forest

\begin{tabular}{|c|c|c|}
\hline Species & Species & Species \\
\hline Acanthus eminens & $\begin{array}{c}\text { Dracaena } \\
\text { laxissisima }\end{array}$ & Phytolaca octandra \\
\hline $\begin{array}{c}\text { Achyrospermum } \\
\text { schimperi }\end{array}$ & Dracaena steudneri & $\begin{array}{c}\text { Podocarpus } \\
\text { falcatus }\end{array}$ \\
\hline $\begin{array}{c}\text { Ageratina adenophora } \\
\text { Ageratum conyzoides }\end{array}$ & $\begin{array}{c}\text { Ficus species } \\
\text { abyssinica }\end{array}$ & $\begin{array}{c}\text { Podocarpus } \\
\text { latifolius }\end{array}$ \\
\hline Albizzia gummifera & Helichrysum sp. & Rhamnus prenoides \\
\hline Alchemila rothii & Hypoestis sp & Rhus natalensis \\
\hline Allophyllus abyssinica & Hypoestis triflora & Leucas bracteosus \\
\hline Asplenium sp. & Hypoestis triflora & Schefflera volkensii \\
\hline Bersama abysinica & Kalachoe pinnata & Solananum sp. \\
\hline Bidens pilosa & Kalachoe sp. & $\begin{array}{c}\text { Solanum } \\
\text { mauritianum }\end{array}$ \\
\hline $\begin{array}{c}\text { Carduus } \\
\text { chamaecephalus }\end{array}$ & Solanum terminale & Leucas sp. \\
\hline Cassaeria battiscombei & Toddalia asiatica & Solanum nigram \\
\hline Cassia didymobotrya & $\begin{array}{c}\text { Urera } \\
\text { hypsolodendron }\end{array}$ & Solanum terminale \\
\hline kilimandischaricum
\end{tabular}




\section{International Journal of Science and Research (IJSR) \\ ISSN (Online): 2319-7064}

Index Copernicus Value (2015): 78.96 Impact Factor (2015): 6.391

Results in the study area indicated that there were 71 identified species distributed in 35 taxa in Kapkanyar Power line in Cherangani Forest and they are presented in table 1 above. Among recorded species are Achyrospermum schimperi, Dombeya torrid, Solanum mauritianum, Prunus Africana and Podocarpus latifoliusamong others.

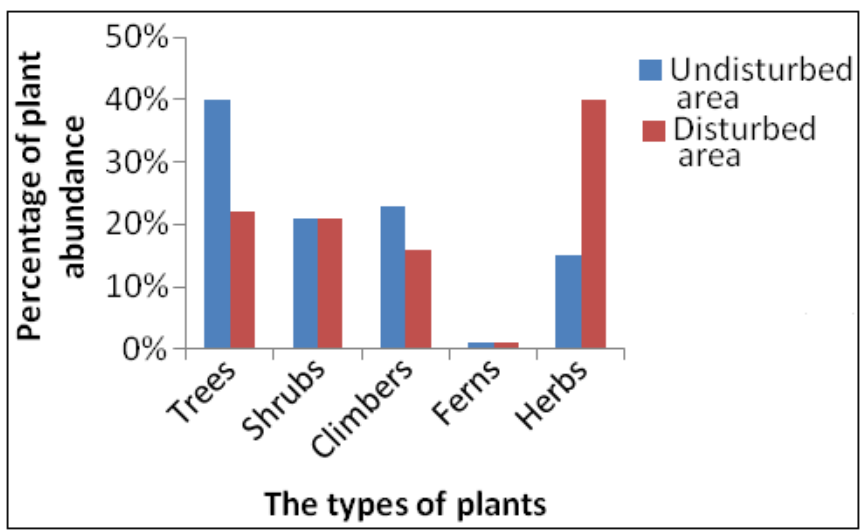

Figure 1: Plant distribution in undisturbed and disturbed areas

Figure 1 above shows the plant distribution in undisturbed areas and disturbed areas. Trees was the most disturbed species as it population reduced from $40 \%$ in undisturbed sites to $22 \%$ in disturbed areas. Consequently abundance of climber seems to be affected by reduced abundance of trees as its population reduced from $23 \%$ in undisturbed sites to $16 \%$ in disturbed sites. However, herbs were affected by construction of Kapkanyar Power line in Cherangani Forest in a positive manner as its abundance increase from $15 \%$ in undisturbed areas to $40 \%$ in disturbed areas. Shrubs and fern seem not to be affected by construction of Kapkanyar Power line in Cherangani Forest.

\subsection{Comparisons between plants abundance in undisturbed and disturbed area}

To determine whether there existed significant differences in the plants species abundance in undisturbed and disturbed area, T-test was conducted. The results are presented in table 2 below.

Table 2: $\mathrm{T}$ test results comparing plants abundance in undisturbed and disturbed area

\begin{tabular}{|c|c|c|c|}
\hline & $\mathrm{t}$ & $\mathrm{DF}$ & Significance (2-tailed) \\
\hline Trees & 8.751 & 2 & 0.001 \\
\hline Climbers & 4.996 & 2 & 0.000 \\
\hline Herbs & 6.853 & 2 & 0.002 \\
\hline
\end{tabular}

According to $\mathrm{t}$ test results above, the $\mathrm{p}$ values of trees, climbers and herbs were $0.001,0.000$ and 0.002 respectively. They were below 0.05 significance level indicating there was a significance difference at $95 \%$ in abundance in undisturbed and disturbed plots in Kapkanyar Power line in Cherangani Forest.
Table 3: Type of trees species disturbed during construction of Kapkanyar Power line in Cherangani Forest

\begin{tabular}{|c|c|c|c|}
\hline $\begin{array}{c}\text { TREE SPP. in Disturbed } \\
\text { Plots }\end{array}$ & TSDA & TSCDPC & Remarks \\
\hline Syzygium guineense & $\mathrm{X}$ & $\mathrm{X}$ & Regenerated (R) \\
\hline Ficus sp. & - & - & Not regenerated (NR) \\
\hline Dombeya torrid & $\mathrm{X}$ & $\mathrm{X}$ & $\mathrm{R}$ \\
\hline Bersama abyssinica & $\mathrm{X}$ & - & $\mathrm{R}$ \\
\hline Neoboutonia macrocalyx & $\mathrm{X}$ & - & $\mathrm{R}$ \\
\hline $\begin{array}{c}\text { Makaranga } \\
\text { kilimandischarica }\end{array}$ & - & $\mathrm{X}$ & $\mathrm{NR}$ \\
\hline Albizzia gummifera & - & - & $\mathrm{NR}$ \\
\hline Cassaeria battiscombei & $\mathrm{X}$ & - & $\mathrm{R}$ \\
\hline Allophyllus abyssinica & - & - & $\mathrm{NR}$ \\
\hline Vepris nobilis & - & $\mathrm{X}$ & $\mathrm{NR}$ \\
\hline Prunus Africana & - & $\mathrm{X}$ & $\mathrm{NR}$ \\
\hline Podocarpus latifolius & - & $\mathrm{X}$ & $\mathrm{NR}$ \\
\hline Podocarpus falcatus & - & $\mathrm{X}$ & $\mathrm{NR}$ \\
\hline Mytenus undata & - & - & $\mathrm{NR}$ \\
\hline 14 & 5 & 6 & $\mathrm{R}=5, \mathrm{NR}=9$ \\
\hline
\end{tabular}

Key: TSDA=Tree species in disturbed area,

TSCDPC $=$ Tree species cut during power line construction

Results shows that the trees species that were affected during construction of Kapkanyar Power line in Cherangani Forest and they have not regenerated were; Makaranga kilimandischarica, Allophyllus abyssinica, Vepris nobilis, Prunus Africana, Podocarpus latifolius and Podocarpus falcatus. All these species were seriously affected by construction of Power line. Species such as Syzygium guineense, Dombeya torrid, Bersama abyssinica Neoboutonia macrocalyx and Cassaeria battiscombei were affected during construction but they have regenerated. Tree species that were not cut down during Power line construction but they disappeared altogether were: Ficus sp. Albizzia gummifera, Allophyllus abyssinica and Mytenus undata.

\section{Discussion}

A total of 71 plant species distributed in 35 taxa were identified in this study (See table 1). A study done by Mutiso et al., (2015) on floristic composition in Mau Forests in Kenya recorded 55 species of mature trees. Also Mutiso, (2011) on a study on post-disturbance tree species regeneration in Blakett and Kedowa forest blocks, Mau ecosystem recorded 45 species. On the other hand Girma et al., (2014) while studying vascular plant diversity of Nandi Forests, Western Kenya recorded high species number of 321 species belonging to 243 genera and 92 families. T -test results showed that there was a significance difference at $95 \%$ in abundance in undisturbed and disturbed plots in Kapkanyar Power line in Cherangani Forest. This could be attributed to cutting down of trees to pave way for Power line construction. Oyugi et al., (2008) who studied effects of human disturbance on composition and structure of Brachystegia woodland in Arabuko-Sokoke Forest, Kenya found a number of differences in the composition and structure of the undisturbed and disturbed sites within Arabuko-Sokoke. One species, J. magnistipulata, reached a high density in the undisturbed site but was absent in the 


\section{International Journal of Science and Research (IJSR) \\ ISSN (Online): 2319-7064}

Index Copernicus Value (2015): 78.96 | Impact Factor (2015): 6.391

disturbed one. Further, results showed more of herbaceous plants in disturbed plots, this could be attributed to the resultant conducive growing space created by disturbance (see figure 1). Javier et al., (1999) reported that since there is increase in size of open spaces that culminates to greater availability of factors that drive plant survival, Also disturbed areas recorded more species populations and predominantly of herbaceous life form. This could be attributed to herbs adaptation to take advantage of the ecological conditions that favor their germination. The population of herbaceous plant is only $15 \%$ of the entire summation, a confirmation that canopy closure restricts the survival of vibrant undergrowth. Cestrum aurantiacum (orange jasmine) an exotic invasive woody weed from America was noted in the first three disturbed plots in descending population magnitudes hence this point to the direction of invasion. Hitimana et al., (2006) in a study on ecology, impact and potential control of $S$. mauritianum in Kenya described $S$. Mauritianum as an alien and invasive gap colonizer associated with forest disturbances. From this result it's clear that forest disturbance has positive correlation with resurgence and proliferation of alien invasive that impact negatively on the ecological equilibrium of species habitats (Joy \& Suzanne, 2004; Pausas $\&$ Austin, 2003). Disturbance or other factors not investigated in this study could be responsible for the species composition. Species associated with disturbance either anthropogenic or otherwise are noted taking control of the ecosystem more strongly in areas affected by the project in question. Henderson, (2001) in the book alien weeds and invasive plants noted that anthropogenic disturbances in most cases favour thriving regeneration and recruitment of colonizers while hindering inhabitant and species of economic significance. The population of ferns remains surprisingly same in both scenarios at one percent. The physiognomy of the undisturbed forest is under the umbrella of keystone species like podocarpus falcatus, podocarpus latifolius, casaeria battiscombei and Dombeya torrida. They overhead other species, and in disturbed sites where they grow, the undergrowth has been taken over by acanthus eminens that resists browsing unless under extreme conditions when other plants' survival has been compromised (See figure 1 and table 3 ).

\section{Conclusions}

Forest disturbance aggravates the spread of invasive alien species leading to ecological imbalance that destabilizes native flora. Results showed significantly higher herbaceous richness in disturbed areas compared to undisturbed area; conversely undisturbed areas had higher tree and shrub richness than undisturbed areas. Trees and shrubs seems require to be aided to adapt to a site. Herbaceous plants are the first colonizers of a site. this usually prepare the site condition for higher plants that are to come later Slow rate of natural regeneration could be attributed to disturbance among other factors not investigated in this study.

\section{Recommendation}

Priority projects that can't avoid forest disturbance should be planned well in advance with relevant ecological and botanical studies instituted prior to the implementation so as to prepare to forestall the anticipated ecological disasters associated with the project. Avoid disturbing forests unless it's extremely beyond ones control or the expected benefits have broad spectrum impact in society.

\section{Reference}

[1] Agnew A.D.Q. (2013). Upland Kenya wild flowers and Ferns. Nature Kenya, East Africa Natural History Society, Nairobi Kenya.

[2] Beentje, H., (1994), Kenya trees shrubs and lianas, National Museums of Kenya.

[3] Birdlife International (2009) Important Bird Area factsheet: Cherangani Hills, Kenya Downloaded from the Data Zone at http://www.birdlife.org on 21/10/2014.

[4] Bridson D. and Leonard F.(1999), the Herbarium Handbook 3rd Ed, Royal Botanic Gardens Kew.

[5] David C. Powell. (2000). Potential Vegetation, Disturbance, Plant Succession, and Other Aspects of Forest Ecology United states department of agriculture.

[6] Gamfeldt, L., Snäll, T., Bagchi, R., Jonsson, M. Gustafsson, L., Kjellander, P \& Mikusiński, G. (2013). Higher levels of multiple ecosystem services are found in forests with more tree species. Nature communications, 4, 1340.

[7] Giriraj.I.M.Murthy and Ramesh (2008).Vegetation composition. Structure and patterns of diversity.Edinborgh journal of botany $65 \mathrm{pg}$ 22.Edinburgh. UK.

[8] Girma, A., Fischer, E., \& Dumbo, B. (2014). Vascular Plant Diversity and Community Structure of Nandi Forests, Western Kenya. Journal of East African Natural History, 103(2), 125-152.

[9] Guisan, A., \& Thuiller, W. (2005). Predicting species distribution: offering more than simple habitat models. Ecology letters, 8(9), 993-1009.

[10] Henderson, L., 2001, Alien Weeds and Invasive Plants, Plant Protection Research Institute Handbook No. 12, 300p.

[11] Hitimana, J., Mutiso, F., Kiyiapi, J., \& Sang, F. (2006, November). Ecology, impact and potential control of S. mauritianum in Kenya. In Proceedings of the $3 \mathrm{rd}$ KEFRI Scientific Conference on Forestry Research in Environmental Conservation, Improved Livelihoods and Economic Development (pp. 6-9).

[12] Intergovernmental panel on climate change. [IPCC](2007), Mitigation 111.

[13] Javier Lopez de Casenavea, Juan Pablo Pelottob, Jorge Protomastro" (1999) Edge-interior differences in vegetation structure and composition in a Chaco semiarid forest, Argentina

[14] Joy B. Zedler and Suzanne Kercher (2004) Causes and Consequences of Invasive Plants in Wetlands: Opportunities, Opportunists, and Outcomes. Botany Department and Arboretum, University of WisconsinMadison, 430 Lincoln Drive, Madison USA.

[15] Meurant, G. (2012). The ecology of natural disturbance and patch dynamics. Academic press.

[16] Musila, W., P. Kirika, J. Kimme, C. Chesire \& I. Malombe (2011). Plant species composition and

\section{Volume 6 Issue 7, July 2017 www.ijsr.net}


diversity in South/North Nandi and Cherangani Hills forests. In W. Musila, I. Malombe \& G. Mwachala (eds.), Strengthening the Protected Area Network within the Eastern Montane Forest Hotspot of Kenya: A rapid biodiversity survey of Nandi Hills and Cherangani Hills Forests. Nature Kenya. Pp 12-22.

[17] Mutiso, F. M., Mugo, M. J., Cheboiwo, J., Sang, F., \& Tarus, G. K. (2015). Floristic Composition, Affinities and Plant Formations in Tropical Forests: A Case Study of Mau Forests in Kenya. International Journal of Agriculture and Forestry, 5(2), 79-91.

[18] Mutiso, F., Mugo, M., \& Cheboiwo, J., 2011, Postdisturbance tree species regeneration and successional pathways in Blakett and Kedowa forest blocks, Mau ecosystem. Research Journal of Environmental and Earth Sciences 3: 745-753

[19] Oyugi, J. O., Brown, J. S., \& Whelan, C. J. (2008). Effects of human disturbance on composition and structure of Brachystegia woodland in Arabuko-Sokoke Forest, Kenya. African journal of ecology, 46(3), 374383.

[20] Participatory forest management plan for Cherangani forest station (PFMP) 2014-2018,(2014) Nature Kenya.

[21]Pausas, Juli G.1\& Austin, Mike (2003), Patterns of plant species richness in relation to different environments: An appraisal.

[22] Pflugmacher, D., Cohen, W. B., \& Kennedy, R. E. (2012). Using Landsat-derived disturbance history (1972-2010) to predict current forest structure. Remote Sensing of Environment, 122, 146-165.

[23] Raffa, K. F., Aukema, B. H., Bentz, B. J., Carroll, A. L., Hicke, J. A., Turner, M. G., \& Romme, W. H. (2008). Cross-scale drivers of natural disturbances prone to anthropogenic amplification: the dynamics of bark beetle eruptions. AIBS Bulletin, 58(6), 501-517.

[24] Tesfaye Ketessa Hundera, and Ensermu Kelbessa (2013).Floristic composition and structural analysis of jibat Humid Afromontane forest west Shewa zone. Ethiopian journal of Education and science. Ethiopia. pg 34.

[25] Timothy O.Randhir and Ayten Erol (2013), Emerging threats to forests: Resilience and strategies.Turkey.American journal of plant sciences.(http://www.scirp.org/journal/ajps)

[26] United Nations Environment Programme (UNEP), 2012. The Role and Contribution of Montane Forests and Related Ecosystem Services to the Kenyan Economy ISBN: 978-92-807-3273-3 Job Number: DEW/1541/NA. 